\title{
Journalist and the Ideology of Media
}

\section{A Phenomenological Study of the Understanding of Pikiran Rakyat's Journalists on Their Media's Ideology}

\author{
Roni Tabroni \\ Department of Communication Science \\ Univeristy of Sangga Buana YPKP \\ Bandung, Indonesia \\ roni_tepas@yahoo.com
}

\begin{abstract}
Being a journalist means that someone becomes part of a particular ideology since every media are not free of value. Being a journalist is also means having to submit and contribute to maintaining the ideology of the media through their works. However, not every journalist understand the existence of the media in which he works, even technically, many journalists who do not have the basic skills of journalism since because the media such as Pikiran Rakyat always open the opportunity to everyone. The method used in this research is qualitative with phenomenology study approach. Research findings on the understanding of Pikiran Rakyats journalists who understand the ideology of the media through an internal training process since not all journalists come from the same majors. Pikiran Rakyat is understood by its ideology as a media that represents the mind of West Javanese people.
\end{abstract}

\section{Keywords-ideology; journalist; local media}

\section{INTRODUCTION}

Mass media is a social institution and mass communication medium that performs journalistic processes, including searching, getting, holding, storing, processing, and conveying information in forms of writings, audios, pictures, audio-visual, data and graphics, etc. by using printed media, electronic media, and all types of channels available. Given that media is linked to general public, there would be diverse interests in it, besides from its main interest, i.e., as an information provider.

As stated on Law No. 40 of 1999, we can see that the core of journalism is information disseminated to general public, that is, an activity or process of searching, collecting, storing, processing, and disseminating information in forms of written data, pictures, and graphics to be disseminated to general public. Public here falls into third interest, that is, media plays a role as a public sphere [1]

It is in the context of interest that we would find an ideology in mass media. In each of its publication, mass media always contains any message that promotes certain ideology and interest. The ideology also contributes in coloring the existence of mass media. For by the ideology, the media would be colored by a system of ideas that contains knowledge, beliefs, norms, and values that are struggled for or upheld by an individual or a group of individual in their social life. That is, mass media has certain guideline, ideas, or ideology in selecting and presenting news. It is the ideology that serves as a reference on how the media determines its contents and presents them in a form of news.

However, what is the most important in media are journalists, which come to be the key player in performing journalistic processes. Therefore, journalists' understanding on their media ideology also strongly affects the ideology of the journalists themselves. As has been alluded to before, it is the ideology that later affects what information to present and how to package it before being presented to general public.

In addition, the role of journalists in understanding the ideology of their media would also influence the journalistic products produced. In turn, the understanding would be a reference and cause for how a journalist select, produce, and package a journalistic product.

The quality of the journalistic product yielded, plus the professionalism of the journalist in processing information into news is affected by the journalist's personal ideology and his or her media's ideology as an outlook or guidance in realizing a certain intention or interest.

The present research explored at least three important aspects, first, the understanding of Pikiran Rakyat's journalists on media ideology. Second, the understanding of Pikiran Rakyat's journalists on their media's ideology. And third, the relation between the understanding of Pikiran Rakyat's journalists products produced and the Pikiran Rakyat's ideology.

\section{RESEARCH METHOD}

The research method used in the present research was a descriptive-qualitative research method. A qualitative research attempts to describe a phenomenon of what the research subject is undergoing, in forms of perception, motivation, action, etc. holistically and descriptively. The main objective of a qualitative research is to understand social phenomena by focusing on a complete description of the phenomenon studied rather than detailing it into some interconnected variables (Rahardjo, 2010).

A descriptive type describes systematically the facts or characteristics of a specific population or area factually and carefully. On the other side, a qualitative research is used because the method can become an instrument of seeing to the extent of which a process takes place on a social phenomenon which is investigated not by a numeric standard but rather 
simply by using a quality standard expressed by a statement (Rachmat, 2009).

A research by using a qualitative method is, according to Bogdan and Taylor, a research procedure that produces descriptive data in form of written or verbal words on the observed phenomena [2].

The types of data collected in the present research were primary and secondary sources, by using an approach of phenomenological study. The phenomenology analyzes the understanding, belief, ideology, and behaviors that could be seen in those informants who have ever undergone or still been undergoing the phenomena studied by the present research.

\section{RESULT AND DISCUSSION}

\section{A. Media Ideology}

Broadly speaking, one can distinguishes two different methods of sense making on ideology concept: (a) soft sense making-ideology is understood more as a belief system which comes to be a character of a certain group of community; and (b) hard sense making - ideology is understood as a belief system that comes to be an aspiration or desire of community which then provides a reference for viewing and/or understanding realities.

Being close to the second sense making in the context of media social, Marxists and neo-Marxists usually use a term of ideology to refer to a belief system that justifies or bases the actions of those people with power to seek distortion and presentation that inclines to be manipulative of realities.

Accordingly, a study of media ideology apparently concerns with images or representations of community realities that media present in various packages of messages which define reality by a certain means using a set of symbol systems.

It means that media ideology is basically main ideas or values that mass media carries by messages conveyed to general public either in forms of news package, ads, films, soap opera program, or reality show program. Media ideology appears explicitly in form of meaning system contained in symbol systems that may be helpful in defining and/or explaining a reality though it is often bias, and providing a reference for public to think, behave, and respond. In the other words, the concept of media ideology is closely attached to other concepts such as belief system, basic way of thinking, worldviews, and values that media carries [3].

The theory used in the present research was the effect of media content or hierarchy of influence developed by Pamela Shoemaker and Stephen D. Reese takes into account some drives that affect media regularly and shows how an effect at one level may interact with an effect at another level (Prihandini: 2008).

Shoemaker and Reese propose 5 (five) levels that may affect the media content, namely: individual, routines, organizational, institution, and ideological/socio-cultural. The five layers indicate that the effect on the media content may takes place from the smallest level to the greatest one.

The theory of the effect of media content makes up different viewpoints on the making of media content, one of which proposed by Gitlin (in Prihandini, 2008). Media content is affected by both socialization and attitude of media workers. This is an approach that centers on communication and emphasizes psychological factor of various aspects on the occupation of each individual, namely professional, personal, and politic.

The content becomes an ideological function and keeps the status quo of the ideology. This approach is also called a hegemony approach, where the greatest effect on media content is positioned as a pressure to supporting status quo and the interest of those who are of power in people.

\section{B. Journalists Understanding of Media Ideology}

In the context of media, ideology apparently concerns with images and representation of community realities that media present in various packages of messages which notabene define reality by a certain means using a set of symbol systems. Thus, what images to establish are and what are to realize by the media depends on what is its media ideology.

The characteristics, aspirations, and even images of a media would be perceived by public based on the journalistic products it produces. Meanwhile, speaking on journalistic products, they are closely related to journalists as the active actors who are directly connected to public through their journalistic products/news. In the other words, the understanding of journalists on their media ideology strongly affect the news produced. Then it is interesting to see how both journalists and their media have synchronized ideology or ideology similarity so that the news they produce serve their mutual aspiration. The understanding of journalists on a media ideology affects more or less both their performance and the content they produce. In this case, the researcher tried to investigate the understanding of Pikiran Rakyat's journalists on media ideology in general.

The earliest identification that is important to know from journalists in relation to media ideology is their educational background. It was found that a majority (60-70\%) of Pikiran Rakyat's journalists were of journalistic or communication background. His aspect is important because in a learning process of journalistic study, mass media ideology is taught.

For Pikiran Rakyat's journalists who didn't come from journalistic or communication department, learning media ideology was done after they have become journalist. Speaking about mass media ideology, they were always directed to their own media (Pikiran Rakyat) they were working for.

Spontaneously, in the end the journalists were all doing as usual, without realizing that whatever he or she do always contain a certain ideology content, either it had been understood before, or it was newly got at Pikiran Rakyat. Thus, ideology matter was not something to consider in making a news content.

Pikiran Rakyat, being the biggest printed media in West Java, held a strong interest in making its contents understood by public. The messages it conveyed by news expectantly not only make people to be informed, from being ignorant, but also hopefully might change something. At the very least, it enlightened its readers.

To build a shared vision on understanding Pikiran Rakyat's ideology, the media should of course begin from a process of recruiting its candidate journalists since the beginning. During 
the selection process, it actually could already be seen how Pikiran Rakyat set criteria so as to produce expected journalists.

In the selection process conducted, the prospective journalists in Pikiran Rakyat ought to meet some requirements. First, technical-administrative aspect. This included skills like writing, journalistic-minded, fluent in foreign language(s), English as a minimum, communicative, supple, educational background of stratum 1, and age no more than 27 years.

Second, insights. After having assessed their capacity by their experience of writing on mass media, they performed a second stage of selection, testing their insight concerning journalistic world and general insights concerning current issues. At this stage, they must write news so as to see to the extent of which their competency on journalistic world is, including their insights on issues feasible to be published as news. At this stage, candidate journalists showed their own competency and insights.

Third, at this final stage, they conducted a psycho-test and interview on the candidate journalists' preparedness to get a training of becoming Pikiran Rakyat's journalists. It was after accomplishing the training that theywould be officially appointed as journalists for Pikiran Rakyat.

When a candidate journalist was admitted in Pikiran Rakyat, there was no process that provided directly an understanding about an ideology of media, particularly Pikiran Rakyat. The measure Pikiran Rakyat pursuedwas to hold training for its candidate journalists. Among some materials included as the content of training were: Pikiran Rakyat insights, journalist mental building, and journalist skill and insight building.

The trainings that Pikiran Rakyat held for its candidate journalists might expectantly provide insight on media ideology, especially the ideology of Pikiran Rakyat itself. The journalists' understanding on Pikiran Rakyat's ideology was that it connected to only West Java-related issues. The journalists' understanding indicated that Pikiran Rakyat's ideology was West Java-related issues themselves.

Pikiran Rakyat's journalists told that when they wrote on West Java, there should be a factor of proximity with local community. That is, the journalists understood where the direction of the media was, that is, as a West Java media that prioritizes West Java-related issues. Thus, even on both national and international issues. Pikiran Rakyat would try to link them to West Java.

Pikiran Rakyat's journalists were fully aware that each media has its own ideology, and Pikiran Rakyat was not an exception. When the issues published were always connected to West Java, they perceived that Pikiran Rakyat was indeed closely related to West Java. Therefore, what contents they produce were would be certainly directed to West Java's interest.

West Java insight should be prioritized by the journalists when making news. Both contents and issues selected have to be connected to West Java. For it was simply futile to make any news unrelated to West Java. How well they might be, they would be rejected or set aside by editorship.
Here, Pikiran Rakyat tried to match the understanding of its journalists on the media they were working for. The matching was performed by educations it provided. In week one, they were supplied with understanding on Pikiran Rakyat, from the history to the orientation of Pikiran Rakyat. Then, the understanding on its media ideology was learnt while working as Pikiran Rakyat's journalist.

Pikiran Rakyat has declared itself as a West Java media, and thus it is not surprising that the understanding it implanted in its journalists was around West Java issues. The contents produced should be linked to West Java's interests. It is not to say that it published only anything taking place in West Java, but rather any news coming from anywhere, national and international alike, if connected to West Java's interest, would surely be published.

\section{CONCLUSION}

Based on the research the researcher conducted on Pikiran Rakyat's journalists about their understanding concerning Pikiran Rakyat's ideology, it could be concluded as follows: first, in Pikiran Rakyat media its candidate journalists were all subjected to the same training and intakes before being officially admitted to be Pikiran Rakyat's journalist. The treatment included, among others, a stage of recruitment selection to see their competency, experience, and background of the candidate journalists. Next, training was held to test and to educate regarding Pikiran Rakyat media itself and journalistic world, because factually the candidate journalists of Pikiran Rakyat mostly didn't come from journalistic or communication department. Second, Pikiran Rakyat's ideology could be inferred from the goals, directions, and characteristics of its news, that is, Pikiran Rakyat prioritized West Javaconnected issues, whereas national and international issues could be picked up if they have any relation with West Java's interests. In addition, Pikiran Rakyat inclined to cover both sides and prioritized safety firstly, given that it has a historical background where it was ever under government control.

Third, Pikiran Rakyat's journalists, in general, shared an understanding that the news they have to produce was one connecting to West Java because they realized that Pikiran Rakyat was a West Java media. In addition, they endeavored not to make any bombastic, out of 'cover both sides' principle, controversial, and provocative news. Fourth, the relation between media ideology and news produced was that the latter served as a form of conveying media ideology. In this case, Pikiran Rakyat expressed that it was a West Java media by prioritizing West Java-connected issues. The appearance of the characteristics of Pikiran Rakyat would be transmitted to public as an ideology of the media, that is, Pikiran Rakyat tended to seek safety firstly in each publication.

\section{REFERENCES}

[1] Mahpuddin.2004. Ideologi Media Massa Dan Pengembangan Civil Society. ISSN 1411-3341. (Hal.191-192)

[2] Moleong, J. Lexy. 2006. MetodologiPenelitianKualitatifEdisiRevisi. PT. RemajaRosdakarya. Bandung, hlm. 4

[3] H. Pawito. 2014. Meneliti Ideologi Media : Catatan Singkat. Vol. 7, No. 1, April 2014. (hal. 6-7) 